\title{
Dekomposisi Termal Pirolisis terhadap Rendemen dan Komposisi Senyawa Kimia dalam Asap Cair Kulit Buah Kakao
}

\author{
Mohammad Wijaya $^{1 *}$, Muhammad Wiharto ${ }^{2}$ \& Army Auliah ${ }^{1}$ \\ ${ }^{1}$ Jurusan Kimia FMIPA Universitas Negeri Makassar, Indonesia \\ Jl. Malengkeri, Kampus UNM Parangtambung 90224 Makassar \\ ${ }^{2}$ Jurusan Biologi FMIPA Universitas Negeri Makassar, Indonesia \\ Corresponding author: wijasumi@unm.ac.id
}

\begin{abstract}
Article history
March 2020

DOI:

\section{Kata-kata kunci:}

Kulit Buah kakao,

Pirolisis lignin,

Asam karbamat
\end{abstract}

Received: $10^{\text {th }}$ February 2020

Received in revised form: $8^{\text {th }}$

Accepted: $21^{\text {st }}$ May 2020

10.17977/um0260v3i22019p018

\begin{abstract}
Abstrak
Kakao yang diperoleh dari perkebunan kakao menghasilkan limbah kakao yang dibuang dan berwana hitam pada waktu yang lama akan mengalami pembusukan, Padahal memiliki potensi yang cukup besar. Dengan penggunaan teknologi pirolisis, analisis kulit buah kakao yang berasal dari Kabupaten Enrekang untuk kandungan lignin sebesar 45,61\%, selulosa $37,61 \%$, hemiselulosa $6,40 \%$, dan lainnya sebesar $10,38 \%$. Hasil pembakaran menghasilkan asap cair kulit buah kakao ke dalam destila dan arang. Dalam penelitian ini digunakan suhu pirolisis $114-514{ }^{\circ} \mathrm{C}$. Rendemen asap cair kulit buah kakao Kabupaten Enrekang pada suhu pirolisis $114{ }^{\circ} \mathrm{C}$ sebesar 8,04\% selama 88 menit, dan pada suhu pirolisis $214{ }^{\circ} \mathrm{C}$ sebesar 28,6 $2 \%$ dengan waktu selama 40 menit, selanjutnya pada suhu pirolisis $314{ }^{\circ} \mathrm{C}$ sebesar $27,65 \%$ dengan waktu selama 83 menit, dan suhu pirolisis $414{ }^{\circ} \mathrm{C}$ sebesar $25,08 \%$ dengan waktu selama 45 menit, akhirnya suhu pirolisis $514{ }^{\circ} \mathrm{C}$ sebesar 8,04\% dengan waktu selama 88 menit. Analisis GC MS untuk asap cair kulit buah kakao adalah asam karbamat, asam asetat, 1H-Pirol, tert-Butilakrilat, propane diamida, asetamida, n-metil, 1-pentena-2-ol, corilon, 5-valerolakton, 4-metoksifenol, $\mathrm{N}$ metilsuccinimida, siklopropilkarbinol, 2-propilamina, etil metakrilat, 1,2-oksaborol, 2,6-dimetil-metoksifenol, namilasetat, sikloheksena karboksilat, 2-proponon, levoglukosan, D-o-asetil, asam heksadekanoat, 1,10-dekadiol, asetiloksi, tetracosaheksaena. Hasil pemisahan senyawa kimia bio aktif dari asap cair kulit buah kakao digunakan untuk memperoleh produk komposisi kimia dengan pengelompokkan senyawa berdasarkan metode PCA.
\end{abstract}

\begin{abstract}
Cocoa plants are obtained from existing cocoa plantations in Enrekang Regency, South Sulawesi. Where cacao fruit produces cocoa pods that are discarded, scattered and black in colour for a long time will undergo a process of decay, even though it has considerable potential. The results of cocoa processing produce cocoa waste. with the use of pyrolysis technology. analysis of lignin content of cocoa pods from Enrekang Regency was 45.61\%, cellulose was 37.61\%, hemicellulose was 6.40\%, and other was $10.38 \%$. The result of this combustion produced liquid smoke of cocoa pods into distillates, charcoal. In this study, pyrolysis temperature 112-512 ${ }^{\circ} \mathrm{C}$ was used. The yield of liquid smoke of cocoa pods in Enrekang Regency at a pyrolysis temperature of $114{ }^{\circ} \mathrm{C}$ was $8.04 \%$ with a time of 88 minutes, and at pyrolysis temperature $214{ }^{\circ} \mathrm{C}$ at $28.62 \%$ with time for 40 minutes, then at pyrolysis temperature $314{ }^{\circ} \mathrm{C}$ at $27.65 \%$ with time for 83 minutes, and pyrolysis temperature $414 \square \mathrm{C}$
\end{abstract}


at $25.08 \%$ with time over 45 minutes, finally the pyrolysis temperature of $514{ }^{\circ} \mathrm{C}$ was $8.04 \%$ with a time of 88 minutes, Analisis GC MS Carbamic acid, Acetic acid, 1H-Pyrrole, tert-Butyl acrylate, Propane diamide, Acetamide, N-methyl, Propanamide, 5-Valerolactone, Phenol, 4-methoxy, NMethylsuccinimide, Cyclopropyl carbinol, 2-Propanamine, N-(1-methylpropylidene), Ethyl methacrylate, 1,2-Oxaborole, 2,3,4-triethyl-2,5-dihydro-5,5-dimethyl, 2,6-Dimethoxy phenol, 1,4Benzenediol, n-Amyl acetate, -1-cyclohexene carboxylate, 2-Propanone, 1,6-Amhydro beta-DGlucopyranose (levoglucosan), Hexadecanoic acid, 1,10-Decanediol, Pregn-16-en-20-one, 3(acetyloxy)-2,6,10,15,19,23-Hexamethyl-2,6,10,14,18,22,-tetracosahexaene. The results of the separation of bio-active chemical compounds from the liquid smoke of cocoa pods are used to obtain chemical composition products by PCA method.

\section{PENDAHULUAN}

Tanaman kakao secara Nasional yang berada pada lahan perkebunan kakao belum mencapai nilai optimal, terutama produktivitas kakao yang menurun akibat perawatan yang kurangdan serangan hama penyakit kakao. Mutu biji kakao yang rendah menjadi penyebab penanganan pasca panen yang belum selesai dan biji kakao yang dihasilkan belum terfermentasi. Kulit buah kakao dengan konsep waste to wealth and recyclable material untuk mereduksi pencemaran lingkungan dan pembanguan berkelanjutan (Daud et al. 2013). Untuk itu perlu dilakukan penelitian lebih lanjut, Kakao dan produk turunan (Cocoa powder, cocoa liquor dan chocolates) terdiri atas polifenol dan perbedaan tingkat potensial antioksidan. Biji kakao mengandung polifenol. Kakao dan produk turunan nya (cocoa powder, cocoa liquor dan cokelat) mengandung konsentrasi polyphenol yang bervariasi. Polifenol dalam biji kakao berkontribusi sekitar 12-18\% dari berat kering dari seluruh kulit buah kakao. Produksi etanol dan biomassa dari biji kakao dengan Palm wine yeast (Mbajiuka et al. 2015). Keberadaan limbah kulit buah kakao belum banyak dimanfaatkan, padahal memiliki potensi yang cukup besar sebagai bahan pakan ternak alternatif. Hal ini disebabkan limbah kulit buah kakao mengandung Theobromine yang menyebabkan keracunan pada ternak. Theobromine diduga dapat menghambat pertumbuhan mikroba rumen, sehingga dapat menurunkan kemampuan ternak untuk mencerna dan memanfaatkan nutrisi yang terkandung Kakao memiliki kandungan K cukup tinggi untuk mempertahankan pertumbuhan tanaman akan membantu varietas pemuliaan beradaptasi terhadap lingkungan (Li. et al. 2010). Selama kakao mungkin terkontaminasi dengan PAH dan sebagai akibatnya kakao mungkin juga terkontaminasi (Ziegenhals. et.al. 2009). Tujuan penelitian ini adalah menghasilkan produk asap cair kakao yang berasal dari kulit buah kakao, menganalisis kandungan bahan baku dengan menentukan kadar hemiselulosa, selulosa dan lignin dan menentukan dekomposisi termal dari variasi suhu pirolisis untuk rendemen asap cair kulit buah kakao.

\section{METODE}

\section{Bahan Kimia}

Bahan kimia yang digunakan adalah Aquades, reagen Folin-Ciocalteu, asam tanat $0.2 \%$, $\mathrm{Na}_{2} \mathrm{~S}_{2} \mathrm{O}_{3} 5 \%, \mathrm{Na}_{2} \mathrm{CO}_{3} 5 \%$, asam sulfat $72 \%$, asam nitrat $3.5 \%$, dextrose, kalium bikromat, indikator ferroin, $\mathrm{FeSO}_{4}, \quad$ indikator fenolphthalein, sodium klorit, $\mathrm{NaOH} 0.1 \mathrm{~N}$, asam asetat glasial, sodium sulfit.

\section{Prosedur Kerja}

Buah kakao yang berasal Kecamatan Maiwa Kabupaten Enrekang dibelah, kemudian diperoleh biji kakao. Limbah kakao berupa kulit buah kakao dilakukan proses pengeringan untuk menghasilkan kadar air hingga mencapai 10-20\% (b/b) (SNI). Kulit buah kakao dimasukkan ke dalam kiln yang terbuat dari baja tahan karat yang dilengkapi dengan alat pemanas listrik, tiga kondensator dan dua buah labu penampung destilat Proses pirolisis untuk memasukkan Kulit buah kakao tersebut dimasukkan dengan suhu pembakaran yang digunakan berturut-turut adalah 114-514 ${ }^{\circ} \mathrm{C}$ dengan lama pembakaran selama 5 jam. Asap cair yang dihasilkan yang terbentuk dialirkan melalui setiap tahap ditentukan dengan bagian bawah kiln ke alat pendingin, kondensat ditampung dalam 4 buah labu dengan volume 2 liter. Kondensat yang diperoleh yaitu kondensat A :114 ${ }^{\circ} \mathrm{C}$, kondensat B : $214{ }^{\circ} \mathrm{C}$, kondensat $\mathrm{C}: 314{ }^{\circ} \mathrm{C}$, kondensat D : $414{ }^{\circ} \mathrm{C}$, dan kondensat $\mathrm{E}: 514$ ${ }^{\circ} \mathrm{C}$, ditampung dalam labu pemisah, dikocok dan 
dibiarkan 24 jam dari masing kondensat, untuk mengendapkan ter. Bagian atas larutan kondensat adalah asap cair, senyawa kimia asap cair seperti asam, fenol dan karbonil serta mengalami 3 tahapan dekomposisi yaitu hemiselulosa, selolusa dan lignin.

\section{Karakterisasi Katalis}

Analisis GC MS untuk menghasilkan senyawa kimia yang potensial dan bioaktif dari asap cair. Analisis SEM untuk struktur morfologi. Alat GC-MS menggunakan kolom kapiler BB 5 MS dengan panjang $50 \mathrm{~m}$ dan diameter $0,25 \mathrm{~mm}$ dengan suhu injektor $125^{\circ} \mathrm{C}$, gas pembawa helium dan kecepatan alir 0,6 $\mu \mathrm{l} /$ menit serta volume injeksinya $0,2 \mu \mathrm{l}$. Hasil GC-MS berupa komponen kimia dilakukan perhitungan kadar asam asetat dari setiap fraksi asap cair. Analisis SEM (Scanning Electron Microscopy) untuk sampel morfologi. Analisis XRD menggunakan $D_{\text {Max }} 2200$ VPC diffraction (DMax 22000 VPC, Rigaku, Tokyo, Japan).

\section{Analisis Data}

Botol berwarna gelap yang bersih ditimbang dengan teliti, lalu diisi asap cair, kemudian botol yang berisi asap cair ditimbang lagi. Selanjutnya ditentukan rendemen asap cair dengan rumus sebagai berikut: $\mathrm{W}_{\text {asca }}=$ berat asap cair dan Wsk $=$ berat serbuk kulit kakao yang kering

$$
\text { Rendemen asap cair }(\% \mathrm{~b} / \mathrm{b})=\left(\frac{W_{a s c a}}{W_{s k}}\right) \times 100 \%
$$

\section{HASIL DAN PEMBAHASAN}

\section{Karakterisasi Katalis}

Pirolisis merupakan proses pemisahan asap cair, arang dan gas yang berasal dari limbah kakao berdasarkan perbedaan suhu dan lama pembakaran. Hasil pirolisis kulit buah kakao dengan menghasilkan kadar air sebesar 9,83\%, Sedangkan kulit buah kakao Kabupaten Enrekang dengan kandungan lignin 45,61\%, alfa selulosa $37,61 \%$ dan hemiselulosa $6,40 \%$. Hal ini sebagai dasar untuk mengetahui kandungan senyawa kimia yang bioaktif dalam produk asap cair (Gambar 1).

Kandungan lignin bergantung pada perbedaan jenis raw material dan kondisi suhu pembakar. Lignin tidak mempunyai unit ulang seperti halnya hemiselulosa dan selulosa, tetapi terdiri atas unit fenolat yang kompleks. Lignin merupakan suatu kompleks kopolimer amorf yang terdiri unit guaiacyl (G), p-hydroxyphenyl (H), dan Syringyl (S) yang interkoneksi sebagai ikatan éter dan ikatan C-C (Shen et al. 2015). Hasil penelitian oleh (Wang et.al. 2014), bahwa karaterisasi kayu pinus dengan pirolisis katalis menghasilkan kandungan lignin 28,6 \%, hemiselulosa 30,1 \% dan selulosa 40,8 \%, sedangkan kandungan kulit buah kakao Kabuapten Wajo untuk selulosa 17,27 \%, lignin $52,02 \%$ dan hemiselulosa $19,56 \%$ (Wijaya et.al.2017).

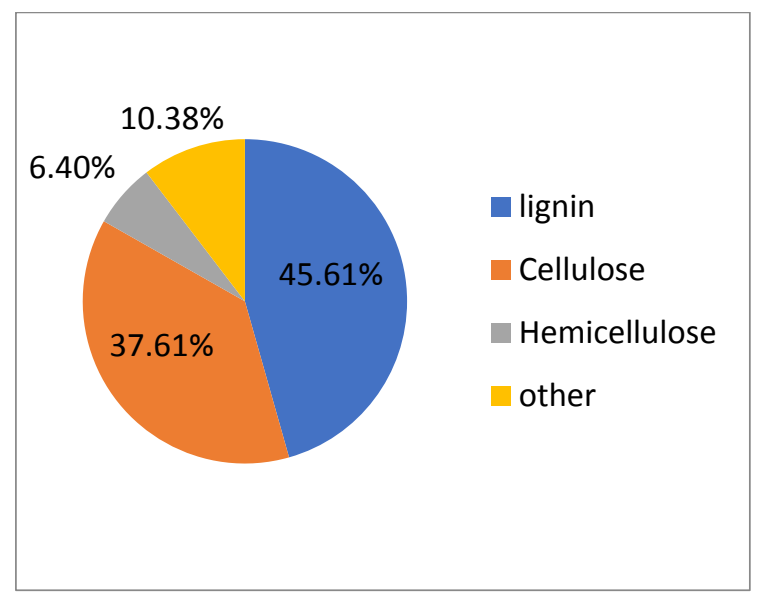

Gambar 1. Analisis kandungan lignin, hemiselulosa, dan selulosa dari Kulit Buah kakao

Hasil analisis GC MS untuk asap cair kulit buah kakao Kabupaten Enrekang (Tabel 1) adalah senyawa-senyawa yang mengandung asam karbamat, asam asetat, $1 \mathrm{H}-\mathrm{Pirol}$, tert-butil akrilat, propane diamida, asetamida, n-metil, 1pentena-2-ol, corilon, 5-valerolakton, 4metoksifenol, N-metalsuccinimida, siklopropil karbinol, 2-propana amina, etilmetakrilat, 1,2oksaborol, 2,6-dimetil-metoksifenol, namilasetat, sikloheksena karboksilat, 2propanon, levoglukosan, D-o-asetil, asam heksadekanoat, 1,10-dekadiol, asetiloksi, tetracosaheksaena. Kelompok senyawa asam (4) adalah asam karbamat, asam asetat, $\mathrm{n}$-amilasetat dan asam heksadekanoat. Sedangkan kelompok senyawa alkohol (5) adalah 1H-pirol, n-metil-1pentena-2-ol, 1,2-oksaborol, 2,6-dimetil-metoksi fenol, 1,10-dekadiol. Kelompok senyawa keton (3) adalah corilon, 5-valerolakton, dan 2propanon.

Hasil rendemen (yield) untuk asap cair kulit buah kakao (Tabel 2), menghasilkan produk asap cair yang terbesar pada suhu $214^{\circ} \mathrm{C}$ diperoleh $33,58 \%$, disusul pada suhu $314{ }^{\circ} \mathrm{C}$ sebesar 22,14 $\%$, selanjutnya suhu $414{ }^{\circ} \mathrm{C}$ sebesar $24,38 \%$, dan suhu $114{ }^{\circ} \mathrm{C}$ sebesar $11,19 \%$ dan terakhir pada suhu $514{ }^{\circ} \mathrm{C}$ sebesar $8,70 \%$. 
Tabel 1. Tabulasi analisis GC-MS asap cair pada buah Kakao
Tabel 2. Rendemen Asap cair kulit buah Kakao Kabupaten Enrekang

\begin{tabular}{|c|c|c|c|c|c|c|c|c|}
\hline \multirow[t]{2}{*}{ Peak } & \multirow[t]{2}{*}{$\begin{array}{l}\text { R. time } \\
\text { (menit) }\end{array}$} & \multirow[t]{2}{*}{$\begin{array}{c}\text { Conc. } \\
(\%)\end{array}$} & Senyawa & \multirow{2}{*}{ No. } & \multirow[t]{2}{*}{$\begin{array}{l}\text { Waktu } \\
\text { (menit) }\end{array}$} & \multirow[t]{2}{*}{$\begin{array}{l}\text { Suhu } \\
\left({ }^{\circ} \mathbf{C}\right)\end{array}$} & \multicolumn{2}{|c|}{$\begin{array}{c}\text { Asap cair Kulit } \\
\text { Buah Kakao }\end{array}$} \\
\hline & & & Carbamic acid & & & & $\begin{array}{c}\text { Massa } \\
(g)\end{array}$ & $\begin{array}{c}\text { Persen } \\
(\% \mathrm{~g} / \mathrm{g})\end{array}$ \\
\hline 2 & 9.209 & 25.78 & Acetic acid & 1 & $08.25-09.53$ & 114 & 25 & 8,04 \\
\hline 3 & 9.675 & 0.96 & 1H-Pyrrole & 2 & $09.53-10.32$ & 214 & 89 & 28,62 \\
\hline 3 & & & & 3 & $10.32-11.55$ & 314 & 86 & 27,65 \\
\hline 4 & 10.175 & 0.65 & tert-Butyl acrylate & 4 & $11.55-12.40$ & 414 & 78 & 25,08 \\
\hline 5 & 11.050 & 0.09 & & 5 & $12.40-13.45$ & 514 & 33 & 10,61 \\
\hline 6 & 11.875 & 5.58 & Acetic acid & & Jumlah & - & & 100,00 \\
\hline
\end{tabular}

$\begin{array}{crrl}7 & 12.384 & 2.18 & \text { Propanediamide } \\ 8 & 12.522 & 4.00 & \text { Acetamide, N-methyl } \\ 9 & 13.225 & 0.10 & \text { Propanamide } \\ 10 & 13.590 & 1.11 & \text { 3-Penten-2-01, (Z)- } \\ 11 & 14.385 & 0.51 & \text { Corylon } \\ 12 & 14.652 & 0.97 & \text { 5-Valerolactone } \\ 13 & 14.849 & 1.52 & \text { Phenol, 4-methoxy } \\ 14 . & 15.045 & 1.63 & \text { N-Methylsuccinimide } \\ 15 & 15.257 & 12.57 & \text { Cyclopropyl carbinol } \\ 16 & 16.075 & 4.79 & \begin{array}{l}\text { 2-Propanamine, } \\ \text { methylpropylidene }\end{array} \\ 17 & 16.505 & 7.85 & \text { Ethyl methacrylate } \\ & 17.276 & 2.68 & \text { 12-Oxaborole 23,4- }\end{array}$

Hasil penelitian ini erat kaitan dengan penelitian oleh (Lv.et al. 2010), bahwa asap cair yang dihasilkan dari proses pirolisis, terdapat juga komponen ter batang jagung pada suhu pirolisis $450,550,700$ dan $900^{\circ} \mathrm{C}$ yang di lakukan analisis GC-MS menghasilkan senyawa organik yang dikategorikan ke dalam keton, furan, asam karboksilat dan alkohol. Kelompok senyawa keton adalah 3-hidroksi-2-butanon, 2siklopenten-1-on, 1-hidroksi-2-butanon, 1hidroksi-2-butanon, 4-hidroksi-3-heksanon. Sedangkan kelompok senyawa furan adalah furfural, dihidro-2(3H)- furanon, dan 2,5 dihidro3,5-dimetil-2-furanon. Asap cair serbuk kayu pinus mempunyai rendemen $10,92 \%, 14,46 \%$, $11,99 \%, 11,32 \%$ dan $0,92 \%$ (Wijaya et al. 2008) triethyl-2,5-dihydro-5, dimethyl-

$19 \quad 17.591 \quad 2.72 \quad$ 2,6-Dimethoxyphenol

$20 \quad 17.921 \quad 3.04 \quad 1,4-B e n z e n e d i o l$
carboxylate

$\begin{array}{llll}24 & 19.300 & 0.76 & \text { 2-Propanone }\end{array}$

$25 \quad 19.671 \quad 5.83 \quad$ Levoglucosan

$20.125 \quad 1.76 \quad$ Alpha.-.Beta.-D26 ribopyranose,1,3-di-oacetyl-

$\begin{array}{llll}27 & 22.158 & 0.78 & \text { Hexadecanoic acid }\end{array}$

$28 \quad 23.618 \quad 0.26 \quad 1,10$-Decanediol

$2931.835 \quad 1.01 \quad$ Pregn-16-en-20-one, (acetyloxy)-

$32.846 \quad 0.20 \quad 2,6,10,15,19,23-$ hexamethyl$2,6,10,14,18,22,-$ tetracosahexaene Menurut Pattiya et. al. 2015, Hasil pirolisis cepat untuk Cassava stalk menunjukkan kadar air sebesar 15,54, abu sebesar 6,01, karbon terikat 14,09 dan kadar zat terbang sebesar 79,90\%.

Hal ini menunjukkan bahwa komponen asap cair pada kulit buah kakao tersebut mengalami proses dekomposisi hemiselulosa dan selulosa, sehingga diperkirakan banyak asam yang terbentuk. Peningkatan keasaman disebabkan oleh pemanasan dan pencucian asam organik dari kayu Eucalyptus (Kartal et.al. 2014). Identifikasi kelompok senyawa fenol, asam, ester, keton, alkohol, furan dan seterusnya, kemudian dilakukan proses pemisahan untuk menentukan senyawa produksi fenol yang berpotensi sebagai 3- bahan dasar kimia. Hal ini didukung oleh penelitian lain, bahwa pirolisis tongkol jagung dengan pembawa panas yang berada pada suhu 430-620 ${ }^{\circ} \mathrm{C}$, memberikan rendemen bio oil maksimun sebesar $14,24 \%$ pada suhu $510{ }^{\circ} \mathrm{C}$. (Guo \& Bi, 2015). Jadi ada hubungan kandungan lignin di dalam kulit buah kakao terhadap 
kualitas asap cair yang dihasilkan dan suhu pirolisis yang mempengaruhi, sehingga diperoleh produksi asap cair yang diinginkan.
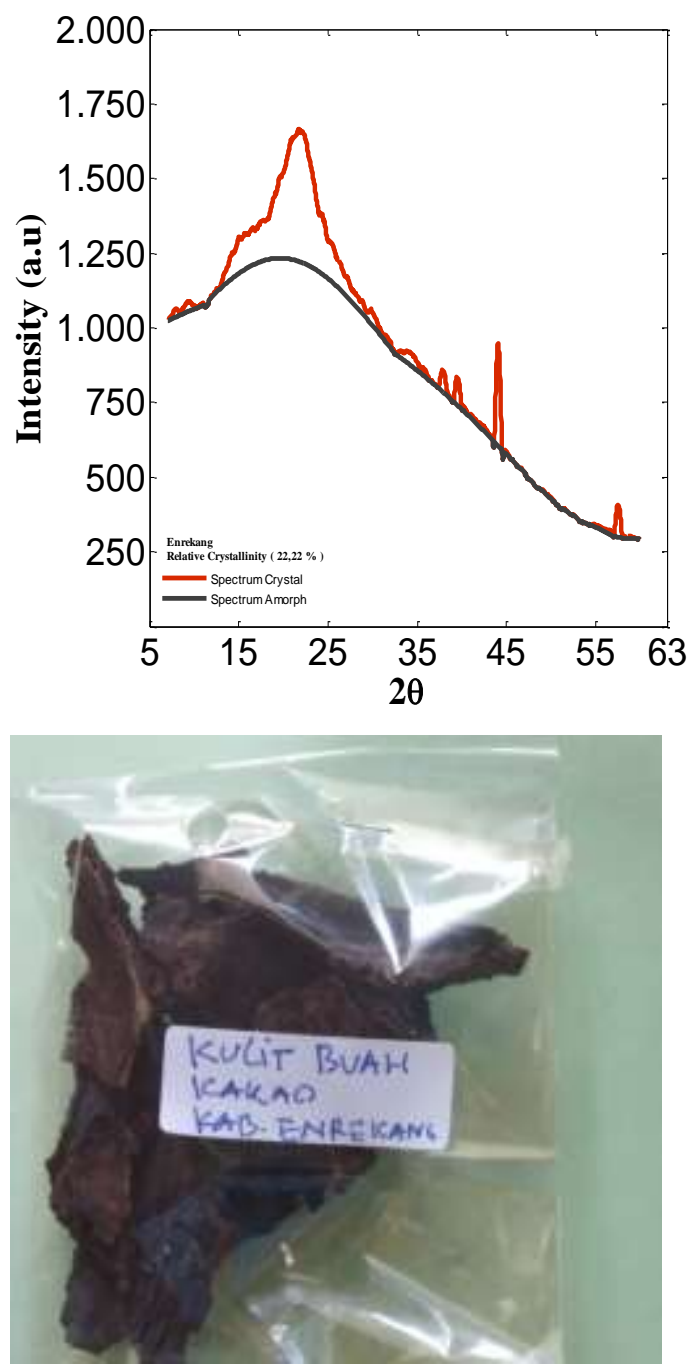

Gambar 2. Pola XRD (atas) dan foto sampel (bawah) kulit buah kakao.

Hasil XRD untuk kulit buah kakao kabupaten Enrekang, menunjukkan bahwa derajat kristalinitas sebesar 22,22\%. Hasil penelitian lain yang terkait oleh Feng, et al. 2015, bahwa hasil analisis XRD untuk bahan limbah minyak kelapa Sawit untuk DS tidak memberikan garis horizontal artinya dalam bentuk amorf sedangkan untuk bentuk kristalin dengan garis mendatar. Jarak difraksi sudut.

Analisis SEM-EDX untuk arang kulit buah kakao (Gambar 3), Ukuran arang kulit buah kakao dengan perbesaran 500, menunjukkan adanya mikropori yang kecil yang mempengaruhi kekuatan unsur. Analisis SEM EDX untuk arang kulit buah kakao Kabupaten Enrekang menunjukkan bahwa unsur $\mathrm{C}$ sebesar
$83,63 \% . \mathrm{Mg}: 1,00 \%, \mathrm{~K}: 6,07 \%, \mathrm{Ca}: 2,28 \%$ dan $\mathrm{Zr}: 3,11 \%$. Sedangkan dalam bentuk senyawa $\mathrm{MgO} 4,05 \% ; \mathrm{K}_{2} \mathrm{O}$ 15,29\%; $\mathrm{CaO} 5,60 \%$, dan $\mathrm{ZrO} 23,35 \%$. Hasil penelitian ini menunjukkan bahwa kandungan carbon yang terbesar dibandingkan dengan unsur lain, sehingga ukuran pori mempengaruhi kekuatan unsur. Hal ini didukung oleh Zhu et al. 2014 bahwa analisis SEM micrograf pada serbuk Silicon Carbide (SiC) menunjukkanpartikel $\mathrm{SiC}$ berada pada jarak 0,2 sampai $1 \mu \mathrm{m}$ Struktur permukaan pada sampel Microcrystaline cellulose (MCC) yang dilakukan pada $90^{\circ} \mathrm{C}, 120^{\circ} \mathrm{C}$, dan $150^{\circ} \mathrm{C}$ untuk analisis SEM menunjukkan ada 2 perubahan yang dilakukan yaitu iregularitas partikel selulosa (Chen et.al. 2014). Rendemen arang mengalami penurunan dari $44,72 \%$ menjadi $31,58 \%$ pada suhu pirolisis yang meningkat 430-620 ${ }^{\circ}$ C.(Guo \& Bi. 2015).

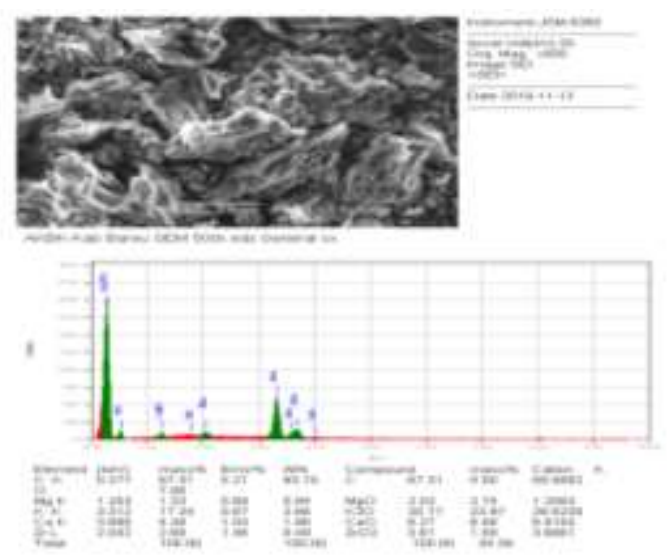

Gambar 3. Analisis SEM-EDX untuk Arang kulit buah kakao Kabupaten Enrekang

\section{KESIMPULAN}

Berdasarkan tujuan dan hasil penelitian dapat ditarik kesimpulan bahwa Hasil pirolisis kulit buah kakao dengan kadar air sebesar 9,829\%,Sedangkan kulit buah kakao Kabupaten Enrekang dengan kandungan lignin untuk kulit buah kakao 45,61\%, Alpha-selulosa 37,61\% dan hemiselulosa $6,40 \%$. Hasil rendemen (yield) untuk asap cair kulit buah kakao menghasilkan produk asap cair yang terbesar pada suhu $214^{\circ} \mathrm{C}$ diperoleh $33,58 \%$, disusul pada suhu $314^{\circ} \mathrm{C}$ sebesar $22,14 \%$, selanjutnya suhu $414^{\circ} \mathrm{C}$ sebesar $24,38 \%$, dan suhu $114^{\circ} \mathrm{C}$ sebesar $11,19 \%$ dan terakhir pada suhu $514^{\circ} \mathrm{C}$ sebesar $8,70 \%$. Hasil analisis GC MS untuk asap cair kulit buah kakao Kabupaten Enrekang, diperoleh senyawa kimia yang potensial diantaranya asam asetat $25,78 \%$, asam karbamat $1,29 \%$, propane amida 2,18\%, asetamida 4,00\%, kloropropyl carbinol $12,57 \%$, propanamina $4,79 \%$, levoglucosan $5,83 \%, \mathrm{n}$ 
Amyl asetat 2,72\%.. Senyawa kimia yang berpotensial untuk dijadikan bahan pangan.

\section{UCAPAN TERIMA KASIH}

Penulis mengucapkan terima kasih atas Dirjen DPRM Kemristek/BRIN RI atas Hibah Penelitian Terapan dan Penulis banyak mengucapkan terima kasih dan penghargaan yang setinggi-tinggi atas fasilitas dan prasarana dalam kegiatan penelitian ini kepada Prof.(R).Dr.Gustan Pari, MS dan Bapak Dadang Setiawan, dan Prof. Dr.Erliza Noor Departemen TIN Fakultas Teknologi Pertanian IPB University Bogor serta Jurusan Kimia FMIPA Universitas Negeri Makassar.

\section{DAFTAR RUJUKAN}

Chen Q, Endo T, Wang Q. 2016. Characterization of Microcrystaline Cellulose after Pretreatment with Low Concentration of Ionic Liquid $\mathrm{H} 2 \mathrm{O}$ for a Pyrolysis Process. J. Biores, 11(1), 159173.

Daud Z, Mohd Kassim AS, Mohd Aripin A, Awang H, Mohd Hatta MZ. 2013. Chemical Composition and Morphological of Cocoa Pod Husks and Cassava Peels for Pulp and Paper Production. Australian Journal of Basic and Applied Sciences, 7(9), 406-411.

Guo M, and Bi J. 2015. Pyrolysis Characteristics of Corn Stalk with Solid Heat Carrier. J. Biores. 10(3), 3839-3851

Feng, J, Xu.K, Shi. Q, Huang X and Li K. 2015. Alga Decay Resistence of Conventional and Noval Wood Based Composites. J.Bioresources. 10(4), 6321-6331.

Kartal SN, Imamura Y, Tsuchiya F, Ohsato K. 2004. Preliminary Evaluation of Fungicidal and Termiticidal Activity of Filtrates from BiomassaSharry Fuel Production. J Biores Technol 95 : 41-47.

Li, YM , Elson M, Zhang D, Sicher RC, Li H, Meinhardt LW, Baligar V 2013. Physiological Traits and Metabolites of Cacao Seedlings Influenced by Potassium in Growth Medium American J. Plant Sciences , 4, 1074-1080

Lv.G.J, Wu.S.B, and Lou. R. 2010. Characteristic of Corn Stalk Hemicelluloce Pyrolysis in a Tubular Reactor. J.Biores. 5(4), 2051-2062.
Mbajiuka, Chinedu, Hediora, AC, Quwuakor CE, Nwokoji L, 2015. Fermentation of Pods Cacao (Theobroma Cocoa L), Using Palm Wine Yeast for Production of Alcohol and Biomass .American J. of Microbiological. Res. 3(2), 80-84.

Pattiya A, Titiloye J, and Bridgwater A. 2015. Fast pyrolysis of Agricultural Residues from Cassava Plantation for Bio Oil Production. As. J. Energy Env. 08(02). 496-502.

Wang, D, Li D, DongcanLv and Liu Y. 2014. Reduction pf the Variety pf Phenolic Compound in Bio Oil via the Catalytic Pyrolysis. J.Biores 8(3), 4014-4021.

Wijaya. M., Noor, E, Irawadi, TT dan Pari.G.2008. Perubaha suhu pirolisis terhadap Struktur Kimia Asap Cair dari serbuk gergaji kayu pinus. J.Ilmu dan Teknologi Hasil Hutan. Institut Pertanian Bogor. 1(2).73-77.

Wijaya M., Wiharto M, dan Anwar. 2017. Kandungan Selulosa Limbah Kakao dan AnalisisKandungan Kimia Asap Cair Kulit Buah kakao dengan Metode GC MS , 3(3) ; 191-197. JKPK UNS.

Ziegenhals, K., Speer, K. and Jira, W. 2009. Polycyclic aromatic hydrocarbons (PAH) in chocolate in the Germany market. Journal fürVerbraucherschutz und Lebensmittelsicherheit 4: 128-135.

Zhu D, Gao. M, Pan H, Pan Y, Liu Y, Li S, Ge H, and Fang N. 2014. Fabrication and mehanical Properties of SiC/SiC-Si Composites by Liquid Si Infiltration using Pyrolysed Rice Husks and SIC Powder as Precursors. 9(2) 2572-2583. 
Wijaya, Dekomposisi Termal Pirolisis terhadap Rendemen dan Komposisi ...

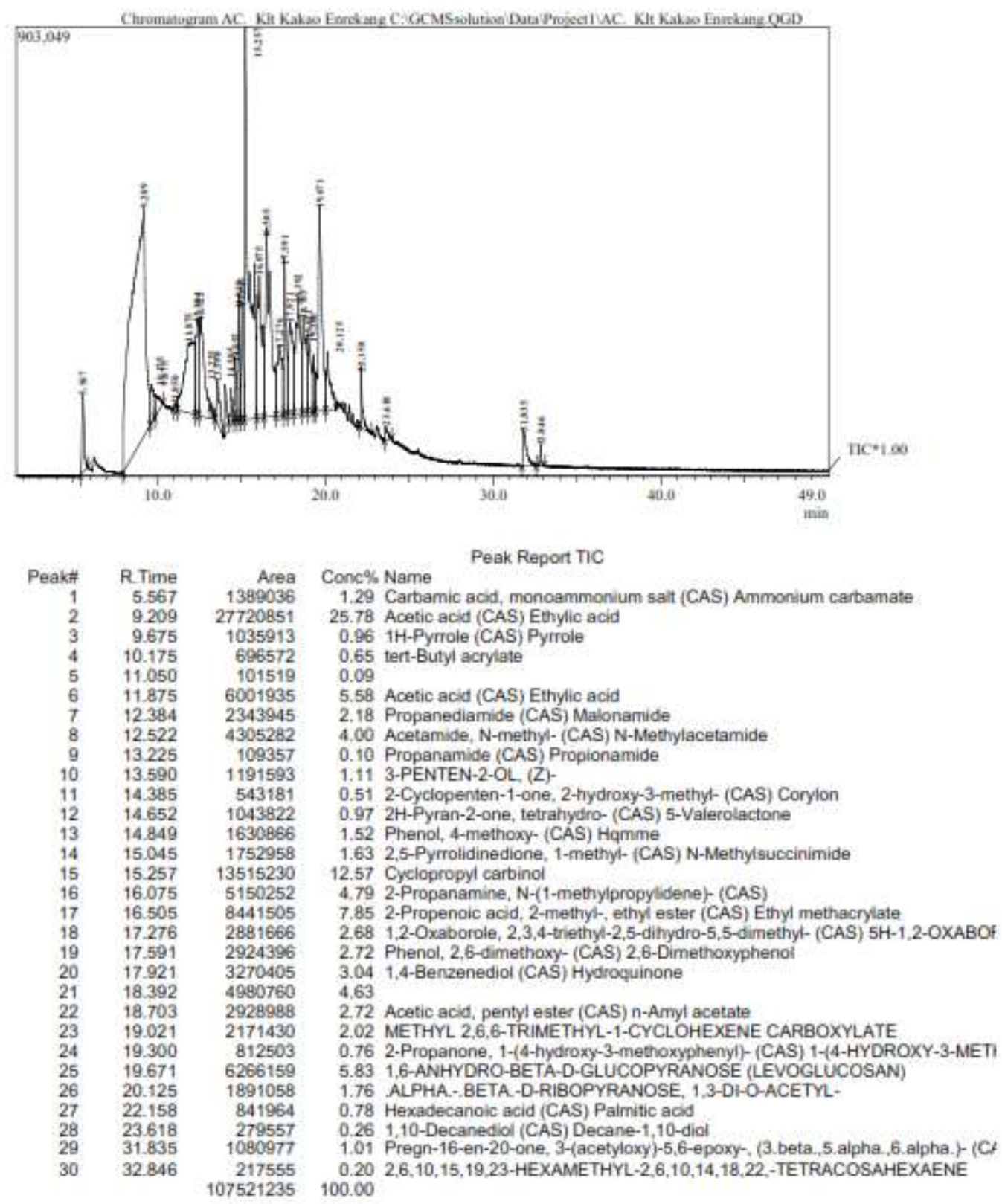

Gambar S1. Analisis GC MS untuk Asap cair Kulit buah kakao Kabupaten Enrekang 